\title{
Originals
}

\section{Antibodies to human albumin epitopes in Type 1 (insulin-dependent) diabetes mellitus}

\author{
R. Mangili ${ }^{1}$, G.C. Viberti ${ }^{1}$ and D. Vergani ${ }^{2}$ \\ ${ }^{1}$ Unit for Metabolic Medicine, United Medical Schools of Guy's and St. Thomas's Hospitals, Guy's Campus, and \\ ${ }^{2}$ Department of Immunology, King's College Hospital School of Medicine and Dentistry, London, UK
}

\begin{abstract}
Summary. The presence of antibodies to glycosylated albumin was studied by means of a newly developed sandwich enzyme-linked immunosorbent assay in 29 long-standing Type 1 (insulin-dependent) diabetic patients with microvascular complications and in 20 normal subjects. Two types of antibody reactivity were detected. One directed against glucitol-albumin expressing $G$ and $M$ isotypes. The second, predominantly belonging to the IgG class, reacted with an epitope shared by non-glycosylated albumin and the ketoamine adduct of albumin glycosylation. Both types of antibodies, with affinity constant ranging from $10^{4}$ to $10^{7}$
\end{abstract}

$(\mathrm{mol} / \mathrm{l})^{-1}$ were found in normal and diabetic subjects, but higher titres were significantly more prevalent in the diabetic patients. These antibodies may represent the result of immune tolerance breakdown or, alternatively, be natural antibodies. Although their function remains to be established, their raised prevalence in Type 1 diabetes may be relevant to diabetic microvascular disease.

Key words: Diabetic microangiopathy, non-enzymatic glycosylation, anti-albumin autoantibodies, glucitollysine.
Nonenzymatic glycosylation of albumin is enhanced in diabetes mellitus [1]. The resulting alteration of molecular structure may render this protein immunogenic. Glycosylated homologous guinea pig low density lipoproteins and albumin as well as glycosylated rat collagen and albumin elicit an antibody response when injected in the same strain of animals [2-4]. Antibodies against glycosylated low density lipoproteins and other proteins have been described in 4 patients with Type 2 (non-insulin-dependent) diabetes mellitus [5]. Moreover, antibodies against reductively glycosylated albumin, but not other forms of albumin, have been found in normal subjects as well as in another three Type 2 diabetic patients [6]. A recent report using an immunoblotting technique has described IgM autoantibodies against non-glycosylated human serum albumin only in a small proportion of diabetic and non-diabetic subjects [7].

The pathogenetic role of these autoantibodies in diabetes remains speculative, but they have been implicated in the pathogenesis of diabetic vascular complications [5]. In this respect it is relevant that a pathognomonic feature of microvascular injury in Type 1 (insulin-dependent) diabetes is a linear deposition of albumin, IgM and IgG along capillary basement mem- brane of kidney, skin, muscles and other vascular areas [8]. The nature of this phenomenon is not fully elucidated, but it cannot be excluded to be the result of formation of immune-complexes between glycosylated albumin and $\mathrm{IgG}$ or $\mathrm{IgM}$.

We have therefore investigated the existence and isotype of antibodies to glycosylated human albumin in Type 1 diabetic patients with established microvascular complications.

\section{Subjects and methods}

Twenty-nine long-standing Type 1 diabetic patients (22 M; $7 \mathrm{~F}$ ) attending the Metabolic Unit at Guy's Hospital were recruited for the study. Their age ranged between 18 and 65 years (mean 40) and duration of diabetes between 14 and 49 years (mean 22 ). A whole range of complications was present in these patients; 20 had persistent clinical proteinuria, with concomitant proliferative retinopathy in 15 , and background retinopathy in 5 cases. Of the other 9 patients, 5 had proliferative retinopathy and 4 had background retinopathy only. Nine patients also had clinical evidence of macrovascular complications including ischaemic heart disease $(n=6)$, cerebrovascular disease $(n=1)$ and peripheral vascular disease $(n=2)$. None of these patients had liver disease or other non-diabetic medical conditions. Their clinical features are shown in Table 1. 
Table 1. Features of Type 1 (insulin-dependent) diabetic patients

\begin{tabular}{|c|c|c|c|c|c|c|c|}
\hline $\begin{array}{l}\text { Subject } \\
\text { no. }\end{array}$ & Sex & $\begin{array}{l}\text { Age } \\
\text { (years) }\end{array}$ & $\begin{array}{l}\text { Duration } \\
\text { of diabetes } \\
\text { (years) }\end{array}$ & $\begin{array}{l}\text { Background } \\
\text { retinopathy }\end{array}$ & $\begin{array}{l}\text { Proliferative } \\
\text { retinopathy }\end{array}$ & $\begin{array}{l}\text { Diabetic } \\
\text { nephropathy }\end{array}$ & $\begin{array}{l}\text { Cardiovascular } \\
\text { complications }\end{array}$ \\
\hline 1 & M & 42 & 29 & - & + & + & IHD \\
\hline 2 & M & 55 & 34 & + & - & + & - \\
\hline 3 & $\mathbf{M}$ & 18 & 15 & - & + & + & - \\
\hline 4 & $\mathrm{~F}$ & 20 & 18 & + & - & + & - \\
\hline 5 & $\mathrm{M}$ & 48 & 41 & - & + & + & - \\
\hline 8 & M & 51 & 25 & - & + & + & IHD \\
\hline 9 & M & 46 & 14 & - & + & + & - \\
\hline 10 & $\mathbf{M}$ & 65 & 20 & - & + & + & CVD \\
\hline 11 & M & 18 & 14 & - & + & - & - \\
\hline 12 & M & 32 & 19 & + & - & + & PVD \\
\hline 13 & $\mathbf{M}$ & 63 & 18 & - & + & + & IHD \\
\hline 18 & $\mathrm{~F}$ & 23 & 14 & + & - & - & - \\
\hline 19 & $F$ & 32 & 22 & - & + & + & - \\
\hline 20 & $\mathbf{M}$ & 43 & 17 & - & + & - & - \\
\hline 21 & M & 31 & 15 & - & + & - & - \\
\hline 22 & M & 45 & 25 & + & - & - & - \\
\hline 23 & $M$ & 38 & 14 & - & + & - & - \\
\hline 24 & $\mathrm{~F}$ & 65 & 27 & + & - & - & - \\
\hline 25 & $\mathrm{~F}$ & 48 & 18 & - & + & + & IHD \\
\hline 26 & M & 33 & 14 & - & + & - & - \\
\hline 27 & $M$ & 36 & 27 & + & - & + & - \\
\hline 28 & $\mathrm{M}$ & 24 & 21 & - & + & + & - \\
\hline 29 & M & 26 & 26 & + & - & - & - \\
\hline
\end{tabular}

$\mathrm{IHD}=$ Ischaemic heart disease $; \mathrm{PVD}=$ Peripheral vascular disease $\mathrm{CVD}=$ Cerebro vascular disease

Twenty healthy subjects recruited from the staff of the Department of Medicine with a similar age (range 22-59, mean 33 years) and sex distribution (14 M:6 F) served as control subjects.

Blood samples were obtained in the fasting state in a plain tube. Sera were decomplemented by heating at $56^{\circ} \mathrm{C}$ for $30 \mathrm{~min}$, aliquoted and stored at $-30^{\circ} \mathrm{C}$ until assayed.

\section{In vitro synthesis of glycosylated albumin}

To remove any amount of glycosylated protein from commercially available human serum albumin (Behring Institut, Marburg, FRG), this preparation was purified by affinity chromatography by loading $90 \mathrm{mg}$ of the protein onto a glass column $35 \mathrm{~cm}$ in length and $16 \mathrm{~mm}$ in width, packed with phenylboronic acid-agarose (Glycogel B, Pierce, Chemical Co, Rockford, III, USA) [9]. The non-glycosylated human serum albumin (NGHSA) obtained in the non-bound fraction was tested for the presence of any glucose residue by the sensitive 2-thiobarbituric acid reaction assay [10]. NGHSA $(30 \mathrm{mg} / \mathrm{ml})$ was incubated under sterile conditions at $37^{\circ} \mathrm{C}$ for $120 \mathrm{~h}$ with $100 \mathrm{mmol} / 1$ glucose (British Drug Houses Ltd, Poole, UK) in the absence or presence of the weak reducing agent sodium cyanoborohydride $200 \mathrm{mmol} / 1\left(\mathrm{NaCNBH}_{3}\right.$, Sigma Chemical $\mathrm{Co}$, Poole, UK) to obtain the ketoamine adduct (KAHSA) or the 1-deoxysorbitol (glucitol) adduct (Glc-HSA) respectively. The latter compound is structurally similar to the Schiff base, a labile product that slowly undergoes the Amadori rearrangement to form the ketoamine adduct, a reduced carboimino group being the only difference with the Schiff base. Such modification renders the glucitol adduct chemically stable [11]. After incubation with glucose, the albumin solutions were dialyzed 6 times against $10^{3}$ volumes of phosphate buffered saline containing $152 \mathrm{mmol}$ sodium, $120 \mathrm{mmol}$ chloride, $4 \mathrm{mmol}$ potassium and $20 \mathrm{mmol}$ phosphate per litre of solution, $\mathrm{pH} 7.4$ at $4{ }^{\circ} \mathrm{C}$; glycosylated adducts were absorbed on phenylboronic acid-agarose, and so separated from NGHSA, and subsequently eluted according to the method of Mallia et al. [9]. After dialysis against phosphate buffered saline, aliquots were stored at $-30^{\circ} \mathrm{C}$.

The average extent of glycosylation was assessed by quantitation of residual free amino groups by the trinitrobenzenesulphonic acid method [12]. l-deoxysorbitol-L-lysine, the putative antigenic determinant of Glc-HSA, was synthesized by the method of Trueb et al. [13].

\section{Determination of titre and isotype of antibodies to glucitol-albumin}

A sandwich ELISA was developed to determine the presence in serum of antibodies to Glc-HSA.

Polvinylchloride microelisa plates (M129A, Dynatech Laboratories Ltd., Billinghurst, Sussex, UK) were freshly coated with $100 \mu \mathrm{l}$ of Glc-HSA at $0.5 \mathrm{mg} / \mathrm{ml}$ in phosphate buffered saline by overnight incubation at $4^{\circ} \mathrm{C}$.

In preliminary experiments using ${ }^{125} \mathrm{I}$ labelled Glc-HSA it was shown that, at this Glc-HSA concentration, approximately $200 \mathrm{ng}$ bind to each well.

Plates were then washed three times with $200 \mu \mathrm{l} /$ well of washing buffer containing $0.05 \%(\mathrm{~V} / \mathrm{V})$ polyoxyethylen-sorbitane monolaurate (Tween 20, Sigma) in phosphate-buffered saline.

Decomplemented serum was serially double-diluted from $2^{-1}$ to $2^{-12}$ in a solution containing $0.5 \%$ Tween 20 and $0.5 \%$ non-immune goat serum (Sigma) in phosphate-buffered saline to prevent non-specific binding to residual reactive sites on polivinylchloride wells; $100 \mu 1$ of every dilution were then added in duplicate to Glc-HSA coated wells and incubated for $60 \mathrm{~min}$ at $4{ }^{\circ} \mathrm{C}$. 
After washing, horseradish peroxidase conjugated rabbit antitotal human immunoglobulins (Dako Ltd, High Wycombe, Buckinghamshire, UK) was used to detect Glc-HSA bound immunoglobulins; human heavy chain $(\alpha, \gamma$ and $\mu$ ) specific horseradish peroxidase conjugated rabbit antisera (Dako Ltd) were used to identify the isotype(s) of Glc-HSA bound immunoglobulins.

In all experiments $100 \mu 1$ of peroxidase conjugated antibody diluted $10^{-3}$ in phosphate buffered saline containing $0.5 \%$ Tween 20 and $0.5 \%$ non-immune goat serum were added to each well and incubated for $60 \mathrm{~min}$ at $4{ }^{\circ} \mathrm{C}$.

After further washing, $100 \mu \mathrm{l}$ of peroxidase substrate $\mathrm{H}_{2} \mathrm{O}_{2}$, freshly made up to a final concentration of $0.12 \mathrm{vols} / 1$ in citrate/phosphate buffer, $\mathrm{pH} 5.0$ at room temperature, containing $0.04 \%$ O-phenylenediamine (Sigma) as chromogen, was added to each well and incubated for $30 \mathrm{~min}$ at room temperature. The enzymatic reaction was stopped by adding $50 \mu \mathrm{l}$ of $4 \mathrm{~mol} / 1 \mathrm{H}_{2} \mathrm{SO}_{4}$ and optical density measured at $492 \mathrm{~nm}$ wavelength by a Titertek Multiskan MC microplate reader (Flow Laboratories, Rickmansworth, Hertfordshire, UK).

In every experiment, series of wells were coated with a solution containing $0.5 \%$ Tween 20 and $0.5 \%$ non-immune goat serum in phosphate buffered saline; the binding of serum samples to these wells provided the non-specific binding. Since the non-specific binding can vary with the immunoglobulin concentration of the sample, both specific and non-specific binding were measured for every sample dilution. Titre was defined as the reciprocal of the highest dilution at which the specific to non-specific binding ratio was greater than 2 .

\section{Determination of binding specificity}

To assess whether binding to the antigen-coated wells was due to antibody, $\operatorname{IgG}$ fractions from all diabetic and control sera with titre exceeding 256 ( $n=10,5$ Type 1 diabetic patients, 5 control subjects) and from 4 low titre $(<4)$ sera $(2$ Type 1 diabetic patients, 2 control subjects) were separated by ion-exchange chromatography on DEAE-Sephacel column $(20 \times 100 \mathrm{~mm})$ (Pharmacia, Uppsala, Sweden); the gel was equilibrated with sodium phosphate buffer $0.01 \mathrm{~mol} / 1, \mathrm{pH}=7.95$ at room temperature and serum aliquots (less than $10 \%$ of gel volume) were applied in each case. IgG containing eluates were then concentrated to the original sample volume using a Minicon B15 concentrator (Amicon Corporation, Danvers, Mass, USA). IgG concentration was measured by radial immunodiffusion (NOR-Partigen plates, Behring Institut, Marburg, FRG), while IgG purity was checked and confirmed by double immunodiffusion using sheep anti-human total serum and anti-human $\operatorname{IgG}, \operatorname{IgM}, \operatorname{IgA}$, C3, C4 (Unipath, Bedford, UK) and rabbit anti-human serum albumin (Dako Ltd).

Binding specificity was tested by competitive inhibition assays. To perform all competition experiments $\operatorname{IgG}$ fractions from each subject were diluted in phosphate buffered saline containing $0.5 \%$ Tween 20 and $0.5 \%$ non-immune goat serum; at the final dilution the specific to non-specific binding ratio always exceeded 5. Aliquots of $500 \mu \mathrm{l}$ of IgG preparations were incubated in liquid phase with four increasing serial 1:10 antigen (Glc-HSA at coating concentration) dilutions (B1-B4) or with buffer only as control (Bo) in plain polypropilene test tubes at $4^{\circ} \mathrm{C}$ for $60 \mathrm{~min} .100 \mu 1$ of each antigen antibody mixture were then added to Glc-HSA coated wells and incubated for $60 \mathrm{~min}$ at $4{ }^{\circ} \mathrm{C}$ : after washing 3 times, horseradish peroxidase conjugated rabbit anti-human $\gamma$ chain was added to detect solid-phase bound antibodies. All samples were tested in quadruplicate.

The optical density which develops in the absence of competitor Bo depends on the absolute amount of IgG that has bound to GlcHSA coated wells. This may be different from subject to subject depending on antibody affinity and dilution factor; thus, in order to compare curves from different subjects, results were plotted considering each point as a percentage of maximum binding (B/Bo plot).

The epitopic specificity and the possible cross-reactivity with re- lated proteins were tested by similar competitive-inhibition ELISAs, measuring the displacement of solid-phase Glc-HSA bound IgG by increasing concentrations of NGHSA, KAHSA, bovine serum albumin (BSA, Sigma) and 1-deoxysorbitol-L-lysine. In these experiments maximum free antigen concentration $\left(B_{4}\right)$ was $862 \mu \mathrm{g} / \mathrm{ml}$ for GIc-HSA, $349 \mu \mathrm{g} / \mathrm{ml}$ for KAHSA, $662 \mu \mathrm{g} / \mathrm{ml}$ for NGHSA and $683 \mu \mathrm{g} / \mathrm{ml}$ for bovine serum albumin. The concentration of glucitollysine was adjusted to reproduce the content of glucitol moieties per molecule of Glc-HSA.

Binding specificity of normal and diabetic samples was further analysed using solid-phase NGHSA and KAHSA as antigens in a competitive-inhibition ELISA. Purified IgG fractions were incubated with $1 \mathrm{mg} / \mathrm{ml}$ of NGHSA or KAHSA in fluid phase for $1 \mathrm{~h}$ at $4^{\circ} \mathrm{C}$ and then tested against the homologous antigen in solid-phase. IgG fractions incubated with NGHSA in fluid phase were also tested against KAHSA in solid-phase. IgG bound to their antigen were revealed by ELISA using horseradish peroxidase conjugated rabbit anti human $\gamma$-chain antiserum.

\section{IgG and IgM binding to non-glycosylated albumin and ketoamine albumin}

The prevalence of IgG and IgM anti-NGHSA and anti-KAHSA was investigated at a single 1:32 serum dilution. The dilution 1:32 was selected on the basis of preliminary observations suggesting a higher frequency of non-specific binding at lower dilutions. Each sample was incubated in wells coated either with NGHSA or KAHSA, using the sandwich ELISA. Results are presented as distribution of specific to non-specific binding ratios.

\section{Antibody affinity}

Apparent affinity constant (Ka) was determined using the competitive inhibition ELISA, from the reciprocal of liquid-phase antigen concentration capable of inducing 50\% antibody binding displacement [14].

\section{Glycosylation of $\operatorname{Ig} G$ fractions}

Nonenzymatic glycosylation of immunoglobulins could theoretically affect their binding affinity and/or their detection by anti-human Ig in solid-phase assays. We therefore glycosylated the IgG fractions from the sera of 5 normal subjects by incubation at $37^{\circ} \mathrm{C}$ for 5 days in the presence of different glucose concentrations $(5,10,20$ and $100 \mathrm{mmol} / 1)$. Aliquots of each incubate were then tested for binding to Glc-HSA and NGHSA by ELISA.

\section{Statistical analysis}

Differences between groups were assessed by unpaired non-parametric tests (Mann-Whitney). Association between variables was evaluated by linear regression analysis.

\section{Results}

\section{Albumin glycosylation}

The average intramolecular glycosylation of Glc-HSA was $50 \%$, as indicated by a $50 \%$ derivatization of lysine residues in the trinitrobenzenesulphonic acid assay. 
Phenylboronic acid affinity chromatography demonstrated that $100 \%$ of the albumin molecules were glycosylated.

Preparation of KAHSA after purification and dialysis contained $55 \%$ glycosylated albumin molecules with an average extent of lysine derivatization of $4 \%$.

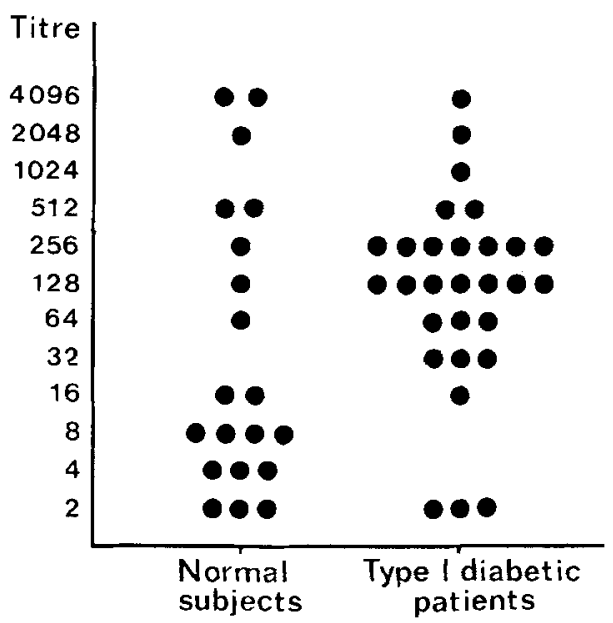

Fig. 1. Titres of antibodies to glucitol human serum albumin (GlcHSA) in 29 Type 1 (insulin-dependent) diabetic patients and 20 normal subjects. Significantly higher titres $(p<0.01)$ were found in Type 1 diabetic patients

Table 2. Isotype of antibodies to glucitol-albumin in normal subjects and Type 1 diabetic patients

\begin{tabular}{llc}
\hline Antibody isotype & $\begin{array}{l}\text { Normal subjects } \\
(n=8)\end{array}$ & $\begin{array}{l}\text { Type 1 diabetic patients } \\
(n=25)\end{array}$ \\
\hline IgG & 2 & 4 \\
IgM & - & 5 \\
IgA & - & - \\
IgG + IgM & 5 & 14 \\
IgG + IgM + IgA & 1 & 2 \\
\hline
\end{tabular}

Non-glycosylated albumin, obtained as the unbound fraction, after elution of a commercial albumin preparation from a phenylboronic acid agarose affinity chromatography column, showed virtually no release of 5-hydroxymethylfurfural after acid hydrolysis, using the 2-thiobarbituric reaction assay. Under our experimental conditions this indicates an average intramolecular glycosylation of less than $1 \%$ and suggests that virtually all of the glycosylated albumin was removed by phenylboronic acid affinity chromatography.

\section{Titre and immunoglobulin isotype}

Figure 1 shows the serum total immunoglobulin binding to Glc-HSA in diabetic and control subjects. Titres ranged from 2 to 4096 in both groups, but their frequency distribution was strikingly different. Type 1 diabetic patients showed significantly higher titres than control subjects $(p<0.01)$. The presence of these antibodies was not related to age, degree of proteinuria or macrovascular disease. The immunoglobulin isotype of the antibody was evaluated in all sera with a titre of 32 or more $(8$ control subjects and 25 Type 1 diabetic patients). IgG and/or IgM antibodies against Glc-HSA were present in all sera. IgG and IgM titres were consistent with, and significantly related to, the binding titre of total immunoglobulins. The regression lines are described by the following equations: Log IgG titre $=1.016$ ( $\log$ total Ig titre) -0.496 ; $(r=0.933 ; p<0.001) . \log$ IgM titre $=0.892($ Log total Ig titre $+0.570 ;(r=0.950 ; p<0.001)$. Low titres of IgA antibodies to Glc-HSA (32, 32 and 64) were found in 1 normal subject and 2 Type 1 diabetic patients only; these three subjects showed also $\operatorname{IgG}$ and $\operatorname{IgM}$ antibodies to Glc-HSA (Table 2).

Table 3. Binding to Glc-HSA of $\operatorname{IgG}$ fractions obtained from 10 high titre anti glucitol-albumin sera. Binding inhibition by increasing amounts of liquid phase glucitol-albumin

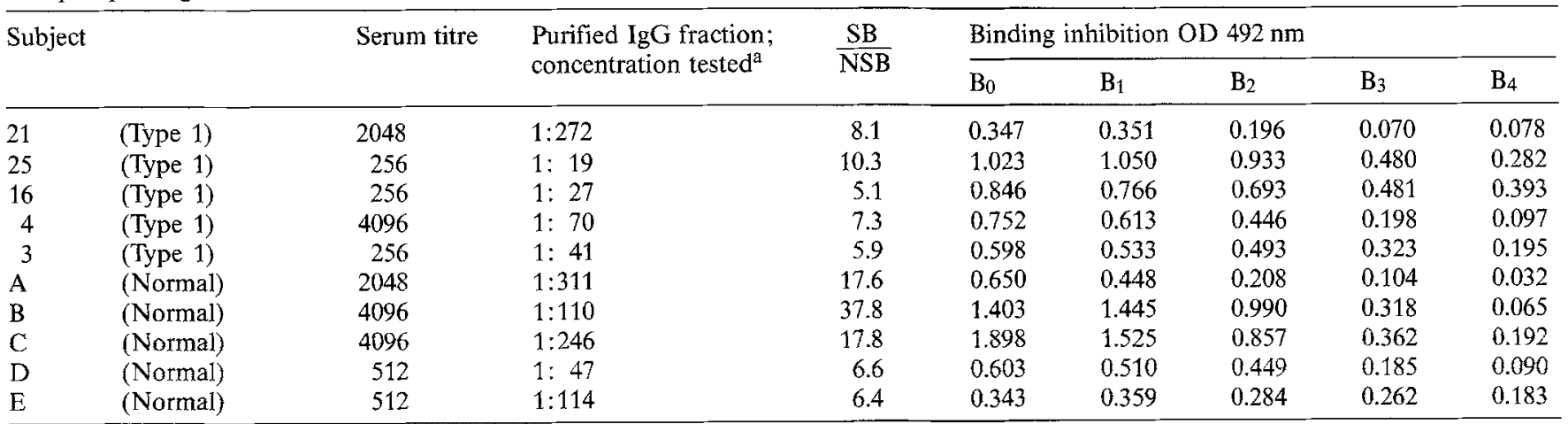

${ }^{a}$ Final IgG dilution in each assay expressed as a ratio of original serum IgG concentration.

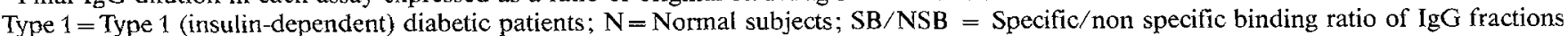
at the given dilution (see text for details); $\mathrm{OD}=$ Optical density; $\mathrm{Bo}=\mathrm{Binding}$ of $\mathrm{IgG}$ in the absence of competitor; B1-B4 = Binding of IgG at increasing competitor (Glc-HSA) concentration (serial 1:10 dilutions). Each value is the mean of four replicates; non specific binding was subtracted from all optical density values; Subject no. is the same as in Table 1 for the diabetic patients. Normal subjects are identified by a capital letter 

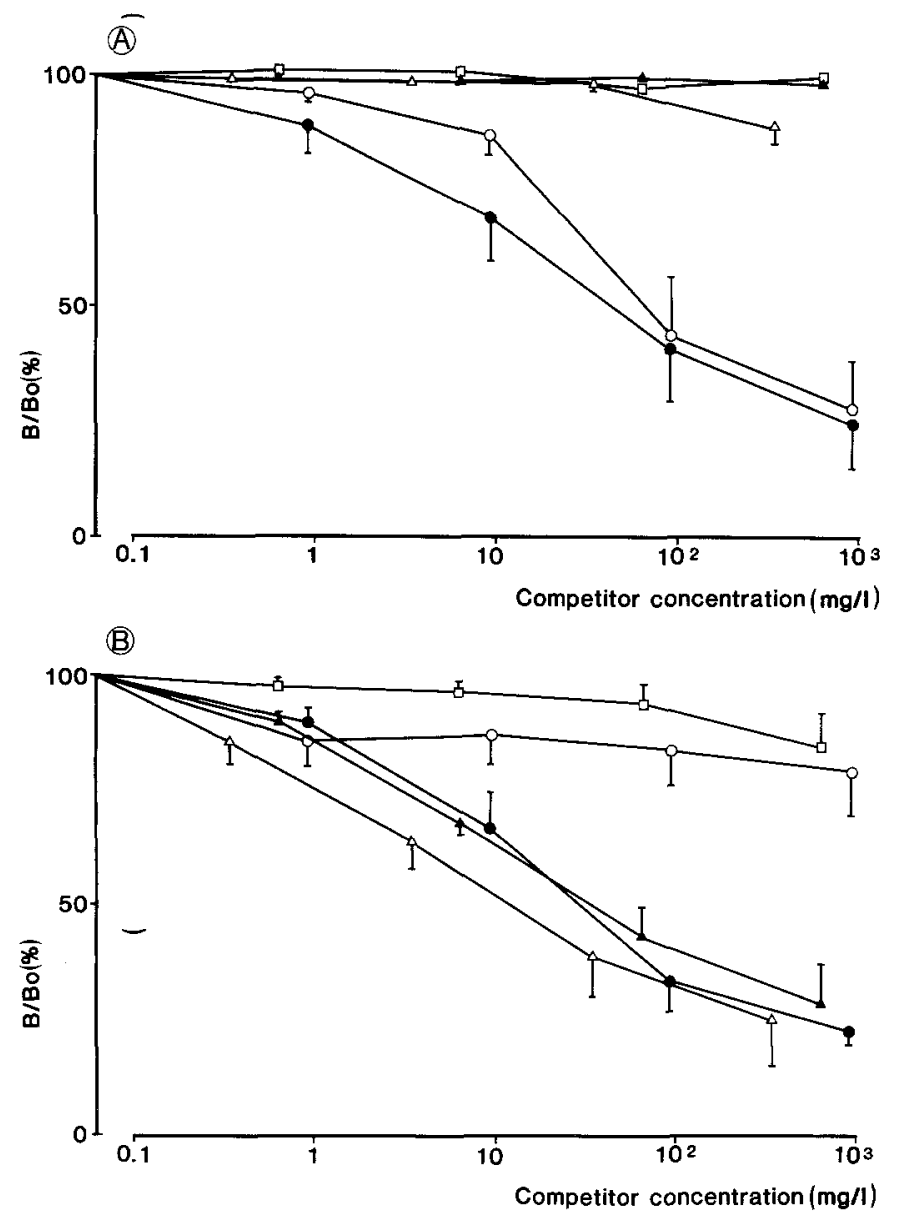

Fig. 2. Competitive inhibition ELISA. Binding displacement of purified $\mathrm{IgG}$ fractions to glucitol human serum albumin (Glc-HSA) by increasing concentrations ( $\mathrm{B}_{1}-\mathrm{B}_{4}$, see text) of Glc-HSA $(\bullet)$, nonglycosylated human serum albumin (NGHSA $\mathbf{A}$ ), ketoamine serum albumin (KAHSA $\triangle$ ), bovine serum albumin (BSA $\square$ ) and glucitollysine $(O)$. Optical densities are presented as percentage of maximum binding $(\mathrm{B} / \mathrm{Bo})$ on the vertical axis. Competitive concentrations are given on the horizontal axis. Panel $\mathrm{A}$ shows the response in 4 normal subjects and 1 Type 1 diabetic patient (type 1 reactivity); panel $B$ represents the response in 1 normal subject and 4 Type 1 diabetic patients (type 2 reactivity, see text for details). Each point represents mean \pm SEM of the percent binding displacement

\section{Determination of binding specificity and cross-reactivity}

IgG fractions obtained from the 10 high titre samples were found to bind to Glc-HSA coated wells. This binding was significantly displaced by an excess of fluid phase antigen in a competitive inhibition ELISA (Table 3). IgGs from the 4 low titre sera did not show a significant binding to Glc-HSA, the specific to nonspecific binding ratio being less than 2 .

Cross-reactivity, tested using IgGs purified from the 5 control and 5 diabetic high titre sera, showed two distinct patterns. In 4 normal subjects and 1 Type 1 diabetic patient the binding to Glc-HSA was similarly displaced by increasing amounts of Glc-HSA and glucitollysine, but not by NGHSA or KAHSA (Fig. $2 \mathrm{~A}$, Table 4A; Type 1 reactivity). In 1 normal subject and 4 Type 1 diabetic patients the binding to Glc-HSA was displaced by increasing amounts of Glc-HSA, but also by NGHSA and KAHSA (Fig. 2B, Table 4B; Type 2 reactivity). The addition of glucitollysine resulted in no displacement in the normal subject and in 2 Type 1 diabetic patients, but gave a partial binding displacement $(40 \%)$ in the other 2 Type 1 diabetic patients (no. 3 and 4, Table 4B). When NGHSA and KAHSA were used as solid-phase antigens, results consistent with these findings were obtained. IgG fractions from sera with type 2 reactivity to Glc-HSA bound to solidphase NGHSA and KAHSA, and the binding was displaced by the homologous antigen in liquid phase at a concentration of $10^{3} \mathrm{mg} / 1$. IgG fractions from sera with type 1 reactivity to Glc-HSA bound to NGHSA and KAHSA to a much lesser extent as expected, even though some degree of specificity for NGHSA was visible (Table 5). In further cross-reactivity experiments it was shown that the binding to solid-phase KAHSA by antibodies with type 2 reactivity was significantly $(p<0.01)$ displaced by NGHSA in fluid phase at a concentration of $10^{3} \mathrm{mg} / 1$ (Fig. 3 ).

Bovine serum albumin did not significantly compete for binding of IgG fractions to Glc-HSA (Fig. 2A and B) or NGHSA and KAHSA. Glycosylation of IgG fractions from sera of normal subjects did not produce an increase in binding to any of the antigens tested.

\section{$\operatorname{Ig} G$ and $\operatorname{Ig} M$ binding to non-glycosylated albumin and ketoamine albumin}

IgG bound significantly to the antigen, as shown by a specific to non-specific binding ratio greater than 2 , in 18 out of 20 normal subjects and 27 out of 29 Type 1 diabetic patients for NGHSA and in 19 out of 20 normal subjects and 27 out of 29 Type 1 diabetic patients for KAHSA.

IgG binding to NGHSA was higher in Type 1 diabetic patients $($ median $=2.8 ;$ range $=1.54-4.53 ; n=$ 29 ) than in the normal subjects (median $=2.3$; range $=$ $1.78-4.44 ; n=20 ; p<0.05)$. Binding to KAHSA, though higher in Type 1 diabetic patients (median $=2.8$; range $1.44-4.68 ; n=29$ ) than in normal subjects (median $=2.4$; range $=1.90-3.52 ; n=20$ ) did not achieve conventional significance $(p=0.07)$. However, when calculations were performed considering only samples showing significant binding (i.e. specific to non-specific binding ratio greater than 2, see Methods section) the difference between normal subjects and Type 1 diabetic patients was significant for both NGHSA (normal subjects: median $=2.4$; range $=$ 2.10-4.44; Type 1 diabetic patients: $\operatorname{median}=2.84$, range $=2.10-4.53 ; p<0.05$ ) and KAHSA (normal subjects: median $=2.45$, range $=2.06-3.52$; Type 1 diabetic patients: median $=2.96$, range $=2.02-4.68$; $p<0.05$ ).

IgM displayed a significant binding (i.e. a specific to non-specific binding ratio greater than 2 ) in a small- 
Table 4. Competitive inhibition ELISA. Cross-reactivity of anti Glc-HSA IgG with nonglycosylated human serum albumin (NGHSA), ketoamine albumin (KAHSA) and l-deoxysorbitol-L-lysine (glucitol-lysine) in 5 normal subjects (N) and 5 Type 1 (insulin-dependent) diabetic patients

\begin{tabular}{|c|c|c|c|c|c|c|c|c|c|c|c|c|c|c|}
\hline \multicolumn{2}{|c|}{ Subject } & \multicolumn{13}{|c|}{ Binding inhibition } \\
\hline & & \multicolumn{5}{|c|}{$\begin{array}{l}\text { NGHSA } \\
\text { OD } 492 \mathrm{~nm}\end{array}$} & \multicolumn{4}{|c|}{$\begin{array}{l}\text { KAHSA } \\
\text { OD } 492 \mathrm{~nm}\end{array}$} & \multicolumn{4}{|c|}{$\begin{array}{l}\text { Glucitol-lysine } \\
\text { OD } 492 \mathrm{~nm}\end{array}$} \\
\hline \multicolumn{15}{|l|}{ A. } \\
\hline 16 & (Type 1) & 0.846 & 0.838 & 0.865 & 0.841 & 0.786 & 0.788 & 0.783 & 0.793 & 0.606 & 0.806 & 0.808 & 0.616 & 0.463 \\
\hline $\mathrm{A}$ & (Normal) & 0.650 & 0.660 & 0.648 & 0.655 & 0.664 & 0.642 & 0.641 & 0.626 & 0.621 & 0.654 & 0.479 & 0.086 & 0.047 \\
\hline \multirow[t]{2}{*}{$\mathrm{E}$} & (Normal) & 0.343 & 0.330 & 0.341 & 0.333 & 0.328 & 0.336 & 0.349 & 0.337 & 0.287 & 0.340 & 0.328 & 0.263 & 0.202 \\
\hline & Median & 0.650 & 0.660 & 0.648 & 0.655 & 0.664 & 0.642 & 0.641 & 0.626 & 0.621 & 0.654 & 0.582 & 0.263 & 0.079 \\
\hline \multicolumn{15}{|l|}{ B. } \\
\hline 21 & (Type 1) & 0.347 & 0.326 & 0.258 & 0.102 & 0.067 & 0.325 & 0.212 & 0.107 & 0.062 & 0.350 & 0.342 & 0.353 & 0.339 \\
\hline 25 & (Type 1) & 1.023 & 1.007 & 0.710 & 0.440 & 0.262 & 1.047 & 0.753 & 0.455 & 0.300 & 1.052 & 1.027 & 0.956 & 1.027 \\
\hline $\mathrm{C}$ & Median & 0.752 & 0.631 & 0.490 & 0.451 & 0.262 & 0.538 & 0.535 & 0.372 & 0.150 & 0.476 & 0.503 & 0.480 & 0.446 \\
\hline
\end{tabular}

Panel A: Subjects with no cross-reactivity with NGHSA and KAHSA-Type 1 reactivity; Panel B: Subjects with cross-reactivity with NGHSA and KAHSA - Type 2 reactivity

Subject identification is the same as for Table 3. Results are the mean of four replicates. Non-specific binding was subtracted from each value. Results were obtained from a single plate for each subject.

$\mathrm{Bo}=\mathrm{IgG}$ binding to solid-phase Glc-HSA in absence of liquid phase competitor; B1-4=IgG binding to solid-phase Glc-HSA at increasing amounts of different competitors in liquid phase (serial 1:10 dilutions); $O D=$ Optical density

Table 5. Binding specificity of antibodies with type 1 (Panel A) and type 2 reactivity (Panel B) to nonglycosylated albumin (NGHSA) and ketoamine albumin (KAHSA)

\begin{tabular}{|c|c|c|c|c|c|c|c|c|c|}
\hline Subject & & \multicolumn{4}{|l|}{ NGHSA } & \multicolumn{4}{|l|}{ KAHSA } \\
\hline Median & & & & 0.065 & 0.033 & & & 0.119 & 0.112 \\
\hline $\begin{array}{r}\text { B. } \\
21 \\
25 \\
4 \\
3 \\
\text { C }\end{array}$ & $\begin{array}{l}\text { (Type 1) } \\
\text { (Type 1) } \\
\text { (Type 1) } \\
\text { (Type 1) } \\
\text { (Normal) }\end{array}$ & $\begin{array}{l}1: 21 \\
1: 15 \\
1: 37 \\
1: 13 \\
1: 20\end{array}$ & $\begin{array}{l}19.6 \\
15.1 \\
12.7 \\
19.2 \\
97.8\end{array}$ & $\begin{array}{l}0.429 \\
0.354 \\
0.176 \\
0.292 \\
1.370\end{array}$ & $\begin{array}{l}0.062 \\
0.047 \\
0.031 \\
0.055 \\
0.100\end{array}$ & $\begin{array}{l}1: 12 \\
1: 40 \\
1: 140 \\
1: 26 \\
1: 43\end{array}$ & $\begin{array}{l}3.8 \\
4.3 \\
5.0 \\
2.9 \\
3.6\end{array}$ & $\begin{array}{l}0.168 \\
0.235 \\
0.216 \\
0.250 \\
0.212\end{array}$ & $\begin{array}{l}0.077 \\
0.090 \\
0.040 \\
0.065 \\
0.086\end{array}$ \\
\hline
\end{tabular}

$\mathrm{Bo}=$ Binding of $\operatorname{IgG}$ fractions to solid-phase NGHSA or KAHSA, in the absence of competitor.

$\mathrm{B}=$ Binding of IgG fractions to solid-phase NGHSA or KAHSA in the presence of NGHSA or KAHSA respectively in fluid phase at a concentration of $10^{3} \mathrm{mg} / 1$. Purified IgG concentration and (SB/NSB) specific to non-specific binding ratio; see Table 3 for details. Subject identification is the same as in Table 4 . Each value represents the mean of 4 replicates

er number of cases: for NGHSA in 5 out of 20 normal subjects and in 6 out of 29 Type 1 diabetic patients; and for KAHSA in 2 out of 20 normal subjects and in 6 out of 29 Type 1 diabetic patients. No difference was found between the two groups in the binding to either NGHSA (normal subjects: median $=1.92$, range $=$ 1.35-2.34; Type 1 diabetic patients: $\operatorname{median}=1.82$, range $=1.48-2.70$ ) or KAHSA (normal subjects: me- 


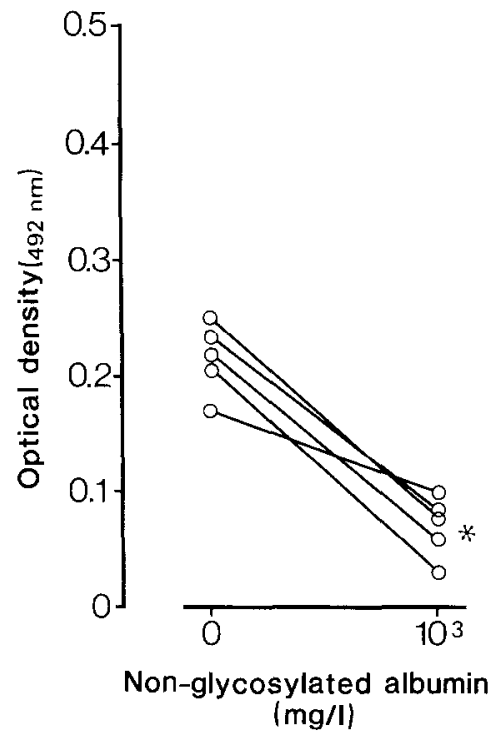

dian $=1.74$, range $=1.34-2.15$; Type 1 diabetic patients: median $=1.90$, range $=1.53-2.51$ ).

\section{Antibody affinity}

The affinity constant (Ka) determined using IgG fractions from the 10 high titre sera, ranged from $10^{4}$ to $10^{7}$ $(\mathrm{mol} / 1)^{-1}$ for Glc-HSA, NGHSA and KAHSA. These ranges were similar for normal subjects and Type 1 diabetic patients.

\section{Discussion}

In this study we document the presence of antibodies to glucitol-albumin in Type 1 diabetic patients. These antibodies mainly showed a $G$ and/or $M$ isotype, only rarely belonging to the IgA class. There was a similar proportion of IgG and IgM class antibodies in our series and this is partly at variance with previous studies reporting a rather lower proportion of $\mathrm{G}$ isotypes [5-7]. Serum of normal subjects also shows a binding to glucitol-albumin. This has been also reported by Nakayama et al. [6] who, however, found no difference in antibody titre between normal subjects and Type 1 diabetic patients; in our study the average titre in normal subjects was lower and the frequency distribution different than in Type 1 diabetic patients.

Furthermore, the epitopic specificity of the $\mathrm{IgG}$ bound to glucitol-albumin was heterogeneous. Antibody with type 1 reactivity specifically recognised the glucitol moiety, being displaced by glucitol-albumin and glucitollysine, but not, to any relevant extent, by ketoamine-albumin or nonglycosylated albumin. However, a weak specific binding to NGHSA was detected when NGHSA was used as solid-phase antigen. The characteristics of this antibody were similar to those described by Witztum et al. [5] and by Nakayama et al.
[6] for anti-glucitol LDL and anti-glucitol albumin antibodies, respectively, and are also consistent with the type of anti-glycosylated collagen antibodies reported in the experimentally diabetic rat [3]. Glucitol adducts of proteins have not been shown to occur in vivo, but it is possible that the immunogenic stimulus is provided by the labile, short lived open-chained ketoamine adduct; experiments in the guinea-pig with glycosylated LDL would support this interpretation [2]. The antibody with type 2 reactivity seemed directed to determinants of the albumin molecule other than glucitol, as suggested by its full cross-reactivity with NGHSA and KAHSA and by the relative failure of glucitol-lysine to compete for its binding. This antibody was found to bind to solid-phase NGHSA and KAHSA and was displaced by the homologous antigen in the liquid phase. Cross-reactivity experiments indicate that the epitope recognised is shared by both NGHSA and KAHSA. The inability to detect an antibody specifically directed against KAHSA does not exclude the possibility that glucose modified albumin is the trigger of the immune response against the albumin molecule. In this respect, interestingly, the levels of IgG isotype antibodies to NGHSA and KAHSA were higher in Type 1 diabetic patients than in normal subjects. This finding suggests that chronic stimulation by antigenically modified albumin may be responsible for an established secondary immune response. The low levels of $\operatorname{IgM}$ isotype antibodies and the lack of difference between normal subjects and Type 1 diabetic patients are consistent with this interpretation. Our results regarding IgM antibodies are in accord with the report by Gregor et al. [7] who, using a qualitative technique, demonstrated $\operatorname{IgM}$ antibodies to non-glycosylated human serum albumin in a small percentage of diabetic patients and normal subjects. However, we could not confirm the higher frequency in Type 1 diabetic patients.

Antialbumin antibodies have been described in chronic liver disease [15], prolonged nitrofurantoin administration [16] and in cryoglobulinaemia [17]. None of these conditions was present in our subjects. In vitro glycosylation of $\mathrm{IgG}$ fractions from normal subjects did not result in an increased affinity either for glucitol-albumin or for nonglycosylated albumin, thereby excluding the possibility that the higher titres more frequently observed in the diabetic patient sera were due to the higher degree of IgG glycosylation.

The antibodies described here may represent the result of immune tolerance breakdown or they may be natural antibodies $[18,19]$ as their presence in normal subjects and relatively low affinity would suggest. Rabbits rendered tolerant to bovine serum albumin lose their state of tolerance when exposed to chemically altered preparations of this protein [20]; structural alterations produced in the albumin molecule by nonenzymatic glycosylation might explain the production of anti-albumin antibodies. 
Grabar has consistently reported the presence of antibodies to serum proteins in normal subjects, and their occurrence is currently more frequently recognised because of the widespread use of sensitive detection techniques [21]. Pools of sera from normal human subjects were shown to contain antibodies to several autoantigens, including serum albumin [22]. Natural antibodies would have a "scavenger" function in clearing and/or transporting metabolic products [23, 24]. An increased load of glycosylated proteins in diabetic patients may result in an enhanced production of specific antibodies. Interestingly, natural antibodies to other carbohydrate moieties of proteins have been described by Sela et al. $[25,26]$. The binding of antibodies to proteins, whether circulating or bound to basement membranes, would lead to increased formation of immune complexes, either in the circulation or in situ. This potentially damaging phenomenon has been described in diabetes [27, 28]. Although the pathophysiological relevance of these antibodies remains to be elucidated, their presence may explain, at least in part, the finding of significantly greater amounts of albumin and immunoglobulins in glomerular and other capillary vessel walls in diabetic patients with micro-angiopathy [8]. Whether these antibodies play a role in the pathogenesis of capillary basement membrane disease [29] must, at present, remain an open question.

Acknowledgments. We thank Prof. H. Keen for encouragement and advice. Dr. R. Mangili was supported by a grant from the Istituto Scientifico San Raffaele, Milan, Italy.

\section{References}

1. Dolhofer R, Wieland OH (1980) Increased glycosylation of serum albumin in diabetes mellitus. Diabetes 29: 417-500

2. Witztum JL, Steinbrecher UP, Fisher M, Kesaniemi A (1983) Nonenzymatic glycosylation of homologous low density lipoprotein and albumin renders them immunogenic in the guinea pig. Proc Natl Acad Sci USA 80: 2757-2761

3. Bassiouny AR, Rosenberg H, McDonald TL (1983) Glycosylated collagen is antigenic. Diabetes 32: 1182-1184

4. Bassiouny AR, Rosenberg H, Thiele GM, McDonald TL (1985) Accelerated onset of albuminuria in diabetic rats preimmunised with glycosylated rat serum albumin. J Clin Lab Immunol 18: 69-73

5. Witztum JL, Steinbrecher UP, Kesaniemi YA, Fisher M (1984) Autoantibodies to glycosylated proteins in the plasma of patients with diabetes mellitus. Proc Natl Acad Sci USA 81: 3204-3208

6. Nakayama H, Taneda S, Aoki S, Komori R, Kuroda Y, Misawa K, Tsushima S, Nakagawa S (1985) Antibodies to non-enzymatically glycosylated albumin in the human serum. Biochem Biophys Res Commun 131: 720-725

7. Gregor I, Iberg N, Berger W, Fluckiger R (1986) Albumin-directed antibodies in diabetes: Demonstration of human serum albumin-directed IgM autoantibodies. Diabetologia 29: 481-484

8. Miller K, Michael AF (1976) Immunopathology of renal extracellular membranes in diabetes: specificity of tubular basement membrane immunofluorescence. Diabetes 25: 701-708

9. Mallia AH, Hermanson GT, Khron RI, Fujimoto EK, Smith PK (1981) Preparation and use of a boronic acid affinity support for separation and quantitation of glycosylated haemoglobins. Anal Letters 14: 649-661
10. Gabbay KH, Sosenko JM, Banuchi GA, Mininsohn MJ, Fluckiger R (1979) Glycosylated Hemoglobins: increased glycosylation of Hemoglobin A in diabetic patients. Diabetes 28: 337-340

11. Garlick RL, Mazer GS (1983) The principal site of nonenzymatic glycosylation of human serum albumin in vivo. J Biol Chem 258: 6142-6146

12. Habeeb AFSA (1966) Determination of free aminogroups in proteins by trinitrobenzensulphonic acid. Anal Biochem 14: 328-336

13. Trueb B, Hughes GJ, Winterhalter KH (1982) Synthesis and quantitation of glucitollysine, a glycosylated aminoacid elevated in proteins from diabetics. Anal Biochem 119: 330-334

14. Nieto A, Gaya A, Jansa M, Moreno C, Vives J (1984) Direct measurement of antibody affinity distribution by hapten-inhibition enzyme immunoassay. Mol Immunol 21: 537-543

15. Tamura N, Suou T, Hirayama C (1982) Anti-albumin antibodies in sera of patients with liver disease. Gastroenterol Jpn 17: $469-475$

16. Lindstrom $P$, Wager $O$ (1978) IgG autoantibody to human serum albumin studied by the ELISA technique. Scand J Immunol 7: 419-425

17. Mills LE, Brettman LR, Jentoft JE, Viner ED, Bernier GM (1983) Crystallocryoglobulinemia resulting from human monoclonal antibodies to albumin. Ann Int Med 99: 601-604

18. Weigle WO (1980) Analysis of autoimmunity through experimental models of thyroiditis and allergic enkephalomielytis. Adv Immunol 30: 159-273

19. Grabar P (1975) Hypothesis: autoantibodies and autoimmune theories: an analytical review. Clin Immunol Immunopathol 4: 453-466

20. Weigle WO (1971) Recent observations and concepts in immunological unresponsiveness and autoimmunity. Clin Exp Immunol 9: 437-447

21. Grabar P (1983) Autoantibodies and the physiological role of immunoglobulins. Immunol Today 4: 337-342

22. Guilbert B, Dighiero G, Avrameas S (1982) Naturally occurring antibodies against nine common antigens in human sera. I. Detection, isolation and characterization. J Immunol 128: 2779-2786

23. Grabar P (1955) Reaction de divers serum normaux avec des substances macromoleculaires naturelles ou synthetiques. Ann Inst Pasteur 88: 11-23

24. Burgen-Wolff A, Berger E (1963) Die Bildung von Antikörpern gegen verschiedene Kuhmilch. Proteine bei Neugeborenen, Kindern, Erwachsenen und Graviden. Experientia 19: 22-23

25. Sela DA, Wang GL, Edelmann GM (1975) Antibodies reactive with cell-surface carbohydrates. Proc Natl Acad Sci USA 72: 1127-1131

26. Sela DA, Edelmann GM (1977) Isolation by cell-column chromatography of immunoglobulins specific for cell-surface carbohydrates. J Exp Med 145: 443-449

27. Abrass CK, Heber D, Lieberman J (1983) Circulating immune complexes in patients with diabetes mellitus. Clin Exp Immunol 52: $164-172$

28. Iavicoli M, Di Mario U, Pozzilli P, Canalese J, Ventriglia L, Galfo C, Andreani D (1982) Impaired phagocytic function and increased immune complexes in diabetics with severe microangiopathy. Diabetes 30: 7-11

29. Brownlee M, Pongor S, Cerami A (1983) Covalent attachment of soluble proteins by nonenzymatically glycosylated collagen. $J$ Exp Med 158: 1739-1744

Received: 8 February

and in revised form: 18 July 1988

Prof. G.C. Viberti

Unit for Metabolic Medicine

4th Floor, Hunt's house

Guy's Hospital

London, SE1 9RT

UK 